\title{
Mandatory Compensation to Commercial Agents upon Termination of Agency under Ethiopian Law
}

\author{
DOI http://dx.doi.org/10.4314/mlr.v11i2.8
}

\section{Abstract}

Kamil Abdu Oumer*

The Ethiopian Commercial Code recognizes mandatory compensation if agency agreement for an indefinite period of time is terminated due to the fault of the principal; and the Draft Commercial Code is likely to maintain this approach. This comment examines the status and functions of a commercial agent as well as the compensation due to the agent upon the termination of the commercial agency. I argue that there should be mandatory compensation upon the termination of agency relations for both definite and indefinite period of time unless the agency relation is terminated due to the fault of the agent that justifies termination of a contract. This is justified by comparative experience in the legal regimes of Germany, France, Britain, the European Union, Turkey and some international conventions on agency relations.

\section{Key terms}

Commercial Agency $\cdot$ Compensation $\cdot$ Indemnity $\cdot$ Agent $\cdot$ Principal

\section{Introduction}

The academic discourse (in transactional agency law) regarding mandatory compensation upon termination of a commercial agency is underway for the last few decades. Many scholars believe that a commercial agent should be entitled for compensation/indemnity if the principal terminates the relation without fault on the part of the agent. Their first justification is that the agent, through his/her/its efforts, has contributed goodwill for the business of the principal that enables the principal to benefit even after the termination of the agency.

\footnotetext{
- Kamil Abdu Oumer (LLB, LLM), Lecturer of Law at Wollo University School of Law, Dessie, Ethiopia. I thank Dr. Elias Nour for his constructive comments. The author can be reached at: Kamillaw2009@gmail.com
} 
Therefore, termination without compensation may be considered as unlawful enrichment for the principal. ${ }^{1}$ The second justification relates to the expense the agent might have incurred in the interest of the business of the principal (before the agency agreement is terminated) and the expected commission the agent would have earned had the relation continued. Termination of agency relations, therefore, may cost the agent the investments he/she has made in expectation of future commission. ${ }^{2}$ Mandatory payment is also justified by the need to protect the commercial agent (usually considered as the weaker party) in the face of a stronger principal.

One of the arguments against mandatory payment is that the principal may shift the cost to the agent for the mandatory payment, and this creates compliance cost. Opponents of mandatory payment also argue that the agent may not be the weaker party in some circumstances and may exacerbate the problem of information asymmetry between the agent and the principal. ${ }^{3}$ The UK Chamber of Commerce, for example, argued that the agent may be more powerful since the principal hires an agent because it lacks the capability to operate by itself. ${ }^{4}$ But, the view of the majority is that the agent is a weaker party and needs legal protection.

Mandatory compensation/indemnity for termination of agency agreements is adopted in various continental legal systems after the legislation of the European Council Directive on the Coordination of the Laws of the Member States Relating to Self-Employed Commercial Agents 653/1986. The same holds true in Britain. However, in most of the states in the United Sates, there is no statutory law that recognizes mandatory compensation. ${ }^{5}$

The Ethiopian Commercial Code also provides for mandatory compensation if a principal terminates an agency agreement for indefinite period of time 'without good cause.' The new Draft Commercial Code also retains the provision by changing 'good cause' to 'force majeure'. The team of National Experts employed by the Addis Ababa Chamber of Commerce and Sectoral Associations has recommended against revision of the provision. ${ }^{6}$

\footnotetext{
${ }^{1}$ Aaron N. Wise (2010), Sales agency Relationships under United States Law, a short guide for the foreign Business person. Available at:

$<\mathrm{http} / /$ www.eurojuris.net/sites/eurojuris.net/files/sales_agency_terminationother_problems_under_us_law--tc_00145021_.pdf $>$. Last visited, March 3, 2017, p5 ${ }^{2}$ Ibid.

${ }^{3}$ QI Zhou (2014), 'Limits of mandatory rules in contract law: an example in agency law', Northern Ireland Legal Quarterly Vol. 65, No.4, pp.357-69, p. 358-359.

${ }^{4}$ Id., p. 361.

${ }^{5}$ Wise (2010), supra note 1, p. 4.

${ }^{6}$ Addis Ababa Chamber of Commerce and Sectoral Associations (2009), 'Position of the Business Community on the Revision of the Commercial Code of Ethiopia. Available at:
} 
This comment examines the legal debate in relation to mandatory compensation to commercial agents upon termination, and it discusses viable options. The first two sections highlight the features of agency relations and briefly discuss the legal status, powers and duties of commercial agents under Ethiopian Law in comparison with laws of other countries and some international conventions. The third section analyses mandatory compensation upon termination of agency agreements under Ethiopian law.

\section{Agency as Tripartite Relation}

Business activities may be conducted by creating direct networks, or using intermediaries or licensing others to produce and sell products. ${ }^{7}$ Commercial agency is one of the intermediary mechanisms for a trader in order to penetrate a new market or boost existing business. A principal trader may prefer to trade within an area through a commercial agent for it may be more affordable than opening a branch; or the principal may want to benefit from the expertise and/or experience of the agent in a certain location.

Commercial agency is usually a tripartite relation among a businessperson, a commercial agent and a third party. Agency relation, therefore, includes the internal relationship between the agent and the principal, and the external relationship which involves the principal and the third party as well as the relation between the agent and the third party. Through agency relationships, the principal benefits from the performance of the agent and is willing to take liabilities. ${ }^{8}$ But, there are doctrinal disagreements as to what agency relations should include; and, in different legal systems, scope of agency relations varies.

In legal systems like Germany, Italy and Sweden, agency contracts are concerned only with the external relations (i.e the relation between the agent and third party as well as the relation between the principal and the third party); and the relation between the agent and the principal is excluded from the concept of agency. ${ }^{9}$ Likewise, the Convention on Agency in the International Sale of

$<$ http://www.ethiopianchamber.com/Data/Sites/1/psd-hub-publications/position-of-thebusiness-community-on-the-revision-of-the-commercial-code-of-ethiopia.pdf $>$. Last visited, march 3, 2017.

7 Robert T. Jones (1972), 'Practical Aspects of Commercial Agency and Distribution Agreements in the European Community', The International Lawyer, Vol. 6 No.1, pp. 107127, pp. 107-127.

${ }^{8}$ Eric A. Posner (2000), 'Agency Models in Law and Economics', The Law School of University of Chicago John M. Olin Law \& Economics. Working Paper No. 92 (2d Series), Available at: $<$ http://www.law.uchicago.edu/files/files/92.EAP_>. Last visited, December 21,2016, p. 4.

${ }^{9}$ Ali Aljasmi (2015), 'Choice of law in respect of agency relationships in the European Union and the united Arab Emirates', A thesis submitted for the degree of Doctor of 
Goods (1983) regulates only the external relation. ${ }^{10}$ The Hague Convention in Relation to Agency, on the other hand, includes the relation between the agent and the principal within the scope of agency relations. ${ }^{11}$ Others like the EU Directive, British statutory law and the French Commercial Code regulate only the internal relation (the relation between the agent and the principal). ${ }^{12}$

In Ethiopia, the Commercial Code has provisions concerning the relation between the principal and the commercial agent. The Code does not define agency. Nor does it contain provisions that govern the relation between the principal and the third party or the relation between the agent and the third party. This is because agency is one of the few transactions that are regulated under both the Civil Code and the Commercial Code, with the latter, inter alia, dealing with special contracts as envisaged under article 1676(2) if the Civil Code. Provisions of the Civil Code shall thus apply on issues which are not covered under relevant Commercial Code provisions.

Article 2199 of the Civil Code defines agency as "a contract whereby a person, the agent, agrees with another person, the principal, to represent him and to perform on his behalf one or several legally binding acts." This provision considers agency as a relation between the agent and the principal, and there are few provisions in the Civil Code that expressly deal with the relation between the agent and the third party, and the relation between the principal and the third party. With regard to tripartite relations, Article 2233 of the Civil Code states that "the legal relations of principal, agent and third parties" shall be subjected to articles 2179-2198 which deal with general provisions of agency law.

\section{Legal Status, Powers and Duties of Commercial Agents}

Agency law regulates both intra-firm governance and inter-party transactions. ${ }^{13}$ In relation to inter-party relations, agency law regulates the tripartite relation

Philosophy Department of Law, University of Essex. Available at:

$<\mathrm{http} / / /$ repository.essex.ac.uk/16227/1/Final\%20version\%20Thesis_\%20Law.pdf $>$ Last visited, December 23,2016, p. 91

${ }^{10}$ The Convention on Agency in the International Sale of Goods, 17 February 1983, Geneva, Article 1(3).

${ }^{11}$ Aljasmi (2015), supra note 9, p. 91.

12 Ellen Eftestøl-Wilhelmsson (2006), 'EC agency law and intermediaries in shipping', Legal Studies Research Paper Series Paper, No 11. 141-178.Available at:

$<$ http://ssrn.com/abstract=1948526>. Last visited, September 3, 2016, p. 143, French Commercial Code, (as updated Until 03/20/2006) article L $134-1$ \& the following, British Commercial Agents (Council Directive) Regulations 30537/1993,

${ }^{13}$ George M. Cohen (2000), 'The Collusion Problem in Agency Law', University of Virginia School of Law Legal Studies Working Papers Series, Working Paper No. 00-2. Available at: $<$ http://papers.ssrn.com/paper.taf?abstract_id=198909>. Last visited, September 3, 2016, p. 3. 
among the principal and the agent, the agent and third party as well as the principal and third party. Also called transactional agency law, it tries to facilitate transactions by "deterring" disagreements between the three parties and resolving them in case dispute occurs. ${ }^{14}$ Its basic principle is that a businessperson "who wants to conduct his business through another person should benefit from the result and should not escape from the liability" thereof. ${ }^{15}$

Classical agency law used to focus on the protection of the principal from the acts of an agent who is empowered to change the legal position of the principal in his actions. Accordingly, agency was considered as a fiduciary relation in which the principal needs protections. ${ }^{16}$ Modern agency law, on the other hand, tends towards the protection of the agent, who is usually considered to be the weaker party, vis-à-vis a stronger principal.

Domestic laws and international/regional agreements in relation to commercial agency define a 'commercial agent' rather than 'commercial agency'. Article 1(2) of the European Convention on the Coordination of the Laws of the Member States Relating to Self-Employed Commercial Agents, for example, defines a commercial agent as " $\ldots$ a self-employed intermediary who has continuing authority to negotiate the sale or the purchase of goods on behalf of ... the 'principal', or to negotiate and conclude such transactions on behalf of and in the name of that principal."

Under Ethiopian law, the status, powers and duties of commercial agents are embodied in two separate legal instruments: the Commercial Code and the Commercial Registration and Business Licensing Proclamation 980/2016. Article 44(1) of the Commercial Code defines a commercial agent as "a person or business organization, not bound to a trader by a contract of employment and carrying out independent activities, who is entrusted by a trader with representing him permanently in a specified area and dealing or making agreements in the name and on behalf of the trader."

\subsection{The legal status of agent and principal in commercial agency, and the issue of citizenship}

There is almost a consensus as to the legal status of the principal as trader in commercial agency relations. But, there are divergent views regarding the legal status of the agent. In some legal systems like Turkey, the legal status of the

\footnotetext{
${ }^{14}$ Ibid.

${ }^{15}$ Paula J. Dalley (2011), 'A Theory of Agency Law', University of Pittsburgh Law Review, Vol. No. 72, pp. 495- 547, p. 497.

${ }^{16}$ Wilhelmsson (2006), supra note 12, p. 142.
} 
agent as a trader is not clear. ${ }^{17}$ In the French Commercial Code, both principal and agent are traders. ${ }^{18}$

Under the Ethiopian Commercial Code, both the commercial agent and the principal are traders. ${ }^{19}$ In the Commercial Registration and Business Licensing Proclamation 980/2016 too, the agent should be "carrying out independent Business activity."20 Therefore, unlike an agent under the Civil Code, commercial agency under Ethiopian law is a trade activity and a commercial agent is a trader that needs commercial registration and licensing to operate in Ethiopia. $^{21}$

At present, international/regional agreements focus on the specific transaction rather than the legal status of the agent. Under the European Council Directive on the Coordination of the Laws of the Member States Relating to Self-Employed Commercial Agents (653/1986), UNIDROIT, Convention on Agency in the International Sale of Goods (1983), and the Hague Convention on the Law Applicable to Agency (1978), there is no requirement for the agent to be a trader. It is not even necessary for the agent to be a professional agent. ${ }^{22}$ Rather, the agent may be trader or non-trader, and may act professionally or occasionally. But, since commercial agency is an income generating professional activity with profit as its sole objective, it is justifiable that the Ethiopian Commercial Code treats commercial agent as a trader.

In UAE's commercial agency law, commercial agency is reserved for nationals. ${ }^{23}$ There is no blanket prohibition of foreigners from engaging in commercial agency in Ethiopia. But, shipping agency services are reserved only

${ }^{17}$ Under the ex-Turkish Commercial Code, an agent had to be a trader. Under the new code, however, there is no express provision. See article 11(2) of the new Turkish Commercial Code 6102/2012.

${ }^{18}$ See French Commercial Code, Article L 134 -1.

${ }^{19}$ Commercial Code of Ethiopia, 1960, Article 5(19) \& 44(1).

${ }^{20}$ See Commercial Registration and Business Licensing Proclamation 980/2016 article 2(9). Whereas the Commercial Code uses Trader, the Commercial Registration and Business Licensing Proclamation 980/2016 uses 'businessperson' instead of trader and 'business activity' in lieu of trade activity.

${ }^{21}$ See Article 5(19) of the Commercial Code of Ethiopia, 1960, and Commercial Registration and Business Licensing proclamation 980/2016.

${ }^{22}$ Aljasmi (2015) supra note 9 , p. 20; See also article 1 of UNIDRIOT (International Institute for the Unification of Private Law), Article 1 Hague Agency, Art 1(2) of EU Agency Directive.

${ }^{23}$ Howard L. Stovall (2008), 'Recent Revisions to Commercial Agency Law in the United Arab Emirates', Arab Law Quarterly Vol. 22, No. 3, p. 310.

$<$ Doi:10.1162/157302508X34379> 
for Ethiopian investors. ${ }^{24}$ It is also clear that a foreign commercial agent may not (on behalf of a foreign trader) engage in areas of investment reserved for domestic investors. Still, it is not clear whether a foreign commercial agent can engage in areas of investment reserved for Ethiopian nationals as representative of an Ethiopian trader.

\subsection{Whether commercial agency solely emanates from contract}

Agency relation may emanate from law, judicial decisions or consensual agreements. But, commercial agency is, "a consensual" relation. ${ }^{25}$ The relation between the agent and the principal emanates from consensual acts. ${ }^{26}$ In the common law legal systems, the consensual act need not be a contract. ${ }^{27}$ In the above regional and international instruments too, there is no requirement for contract. What is required is a consensual empowerment, not necessarily a formal contract. Under some domestic jurisdictions and international conventions -like the Convention on Agency in the International Sale of Goods 1983-, the power of the agent may be either express or implied. ${ }^{28}$ The Convention, further, provides that "the authorization need not be given in or evidenced by writing and is not subject to any other requirement as to form. It may be proved by any means, including witnesses."29

The Commercial Code of Ethiopia and the Commercial Registration and Business Licensing Proclamation 980/2016 use the phrase 'entrusted by a trader/business person/' without specifying whether mere agreement is enough or whether a full-fledged contract between the two is required. In the Amharic

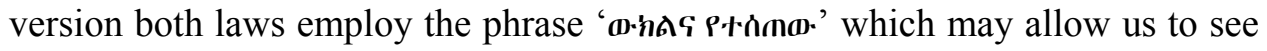
the meaning of agency (ans) from the Civil Code. As indicated above, agency under the Ethiopian Civil Code, among others, is a contract, and it can be argued that the relation between a commercial agent and a principal can only be created through a contract.

If commercial agency emanates from a contract, therefore, the agreement between the principal and the agent should fulfil the basic elements of a contract. Regarding the form in which the agency agreement should be made,

${ }^{24}$ Investment Incentives and Investment Areas Reserved for Domestic Investors, Council of Minister Regulation 270/2012, Article 3.

${ }^{25}$ Eric Rasmusen (2001), 'Agency Law and Contract Formation', Harvard Law School Discussion Paper, No. 323, p. 4. Available at:

$<\mathrm{http}$ ://www.law.harvard.edu/programs/olin_center/> Last visited, October 25, 2016, , p. 4

26 Paula J. Dalley (2011), 'A theory of agency law', University of Pittsburgh Law Review, Vol. No. 72, p. 501.

${ }^{27}$ Thomson Reuters (2015), USA Restatement (Third) of Agency, Westlaw, p. 4.

${ }^{28}$ Convention on Agency in the International Sale of Goods, Articles 1(1) \& 9(1).

29 Id., Articles 1(1) \& 10. 
there are tendencies of differentiating an agency for mere intermediation and agency for the conclusion of contract or power of agency in which the commercial agent has the power to bind the principal through his conduct. In Turkish law, for example, there is a difference in form between the agency to act as intermediary and agency to bind the principal. A commercial agent may not enter into a contract or another obligation that might bind the principal or take delivery of goods for which he personally has not paid or accept payment for goods that he had not personally delivered unless s/he is empowered to do so in a written form, and the same has been registered in the commercial register. ${ }^{30}$

Under the Ethiopian Commercial Code, there is no provision that regulates the form required for commercial agency agreements and there is no distinction between agency to act as intermediary and agency to enter into a binding act in the commercial laws. But, agency provisions in the Civil Code provide that "where the act to be performed by the agent is under the law to be made in a prescribed form, such form shall be complied with in conferring authority upon the agent" and "the agent may not without special authority alienate or mortgage real estate, invest capitals, sign bills of exchange, effect a settlement, consent to arbitration, make donations or bring or defend an action". 31

\subsection{Duration of commercial agency}

Unlike agency in civil transactions, commercial agency between an agent and a principal is not confined to a specific activity, and thus needs to create a relatively long lasting relationship between the two. The agency relation may be for a definite or an indefinite period of time. But, it goes beyond a one-time activity. The French Commercial Code, for example, states that the agent should be "permanently entrusted" by the principal. ${ }^{32}$ Likewise, the European Council Directive on the Coordination of the Laws of the Member States Relating to Self-Employed Commercial Agents 653/1986 provides that the relation need be a continuous one. ${ }^{33}$ The European court of Justice decided that "it is not important whether the agent negotiated one or more contracts so long as he has continuing authority". ${ }^{34}$ However, the Convention on Agency in the International Sale of Goods (1983) and the Hague Conference on Private International Law Convention on the Law Applicable to Agency (1978) do not require continuity.

Under Ethiopian law, a commercial agent represents the principal permanently, which seems to mean until it is terminated according to the law or

\footnotetext{
${ }^{30}$ See Articles $106 \& 107$ of the Turkish Commercial Code No. 6102/2012.

${ }^{31}$ Civil Code of Ethiopia, 1960, Articles 2180 \& 2205 (2).

${ }^{32}$ See French Commercial Code, Article L 134 -1.

${ }^{33}$ European Council Directive on the Coordination of the Laws of the Member States relating to Self-Employed Commercial Agents, 653/1986, Article 1(2),

${ }^{34}$ Wilhelmsson (2006), supra note 12, p. 145.
} 
by agreement. Yet, commercial agency agreement may be made for a specified period of time, as provided under article 52(1a) of the Commercial Code which reads "agency agreement shall terminate where the period of time for which it was entered into expires".

\subsection{Independence of a commercial agent}

A commercial agent acts independently and shall never enter under the audit of the principal. ${ }^{35}$ The agent is not an employee who works under the control of the principal. Even if the agent and the principal retain their independent legal personality, the principal may control the acts of the agent in the way of issuing initial and interim instructions. ${ }^{36}$ But, the agent may refuse to execute instructions from the principal that may challenge its independent existence. ${ }^{37}$

Under Ethiopian law, a commercial agent is not bound by a contract of employment and is free to manage its own day to day activities. While the agent is an independent actor, it also should carry out all instructions of the principal, inform any dealing he has made on behalf of the principal and send periodic reports about his works. ${ }^{38}$ However, there is lack of clarity regarding the nature and extent of instructions that may be issued by a principal to the agent vis-à-vis the level of independence a commercial agent is entitled to.

\subsection{Location and exclusivity of commercial agency}

A commercial agent is usually an exclusive agent empowered to represent the principal within a specific area or in relation with certain customers. Some jurisdictions like the United Arab Emirates (UAE) avoid such exclusive mandates of commercial agents which seem to be inconsistent with antimonopoly regulations. ${ }^{39}$ Others, such as Lebanon, allow exclusivity only for luxurious goods. ${ }^{40}$

Under Ethiopian law, the geographical area in which the agent operates on behalf of the principal need to be specified. Moreover, "unless otherwise provided in the agency agreement, a commercial agent shall be the exclusive

\footnotetext{
${ }^{35}$ Yusuf Korun (2013), ‘Acentenin Hak Ve Borçlari’, T.C.İstanbul Kültür Üniversitesi

Sosyal Bilimler Enstitüsü Yüksek Lisans Tezi. p. 10; Avilable at:

$<$ http://acikerisim.iku.edu.tr:8080/jspui/bitstream/11413/734/1/YusufKorunYLtez.pdf $>$

Last visited, December 21, 2016,

${ }^{36}$ USA Restatement law-agency, supra note 27, pp. 2-3, 6.

${ }^{37}$ Study Group on a European Civil Code Principles \& Research Group on EC Private Law (Acquis Group) (2009), 'Definitions and Model Rules of European Private Law', European law publishers $\mathrm{GmbH}$, Munich, p. 2340-41.

${ }^{38}$ See Article 46 of Commercial Code of Ethiopia 166/1960, Article 46(2a).

${ }^{39}$ Stovall (2008), supra note 19, p. 312.

${ }^{40}$ Ibid.
} 
agent of the principal in the area specified in the agreement". ${ }^{41}$ Therefore, the principal may not appoint more than one agent within a given geographical area unless the agency agreement with the first agent expressly allows so.

Exclusivity is being challenged in different legal systems from the perspective of competition and consumer protection. In Ethiopia too, the Commercial Registration and Business Licensing Proclamation 980/2016, has prohibited operating "as sole importer or sole distributor" except for some business areas that the Council of Ministers may allow through Regulation. ${ }^{42}$ The presumption of exclusivity should be avoided in the absence of contractual agreement to the contrary.

\subsection{The purpose and scope of representation}

A principal trader may authorize the agent for dealing with third parties. The authority may be to enter into a contract, to negotiate or perform contracts or only to introduce the principal. ${ }^{43}$ It does not necessarily have to be the conclusion of a contract on behalf of the principal. Intermediaries (known as introducing agents) -which are authorized only to introduce the principal- are also subject to regulations of commercial agency. ${ }^{44}$

Under Ethiopian law, there is a discrepancy between the Commercial Code and the Commercial Registration and Business Licensing Proclamation 980/2016. Under the Commercial Code, the agent may be entrusted to deal or make an agreement while the Proclamation provides that the agent is empowered to make an agreement. ${ }^{45}$ According to the Commercial Registration and Business Licensing Proclamation, a commercial agent should be empowered to make an agreement on behalf of the principal. This may imply that an agent entrusted to introduce a principal or only negotiate agreements on behalf of the principal is not envisaged under the Proclamation.

According to the Commercial Code, on the other hand, an agent may be empowered to negotiate agreements, to make agreements or both to negotiate and make agreements. As the Proclamation focuses on Registration and Licensing, it is not expected to deal with issues of commercial agency in detail,

${ }^{41}$ Commercial Code of Ethiopia (1960), Article 45.

${ }^{42}$ Commercial Registration and Business Licensing Proclamation 980/2016, Article 38.

${ }^{43}$ Aljasmi (2015), supra note 9, p. 23.

${ }^{44}$ Gregor Kleinknecht, 'commercial agency contracts: termination and indemnity in England and Wales' Capitolo Quinto, pp. 94, 95. Available at: <http://www.hunterssolicitors.co.uk/wp-content/uploads/2016/04/Gregor-Kleinknecht-chapter.pdf $>$ Last visited, March 3, 2017.

${ }^{45}$ See Article 44 of the Commercial Code of Ethiopia (1960) and Article 2(7) of the Commercial Registration and Business Licensing Proclamation 980/2016. 
and thus the provisions of the Commercial Code prevail regarding the scope of a commercial agent's activities.

The Turkish Commercial Code makes a distinction between the power to negotiate and the power to bind the principal. Under the Turkish law, the power to bind the principal should be granted in a written form and should be registered while the power to act simply as an intermediary may be given in any form. As discussed above, there is no such distinction in Ethiopia.

\subsection{Some exclusionary rules on the scope of commercial agency relations}

Various conventions and domestic laws have exclusionary rules which exclude certain relations from the application of commercial agency laws. For example, commercial agents whose activities are unpaid, commercial agents who operate on commodity exchanges or in the commodity market, etc. are not covered under the European Council Directive on the Coordination of the Laws of the Member States Relating to Self-Employed Commercial Agents 653/1986. Moreover, under the EU Directive, commercial agents for negotiating contract for service are excluded from the application of the directive unless the laws of member states provide otherwise. ${ }^{46}$

Likewise, the Ethiopian Commercial Code provides that there is no commercial agency if there is an employment relationship between the parties. ${ }^{47}$ But, if the Ethiopian law further excludes agents regulated under special laws from the scope of the Commercial Code, special regulation would be necessary.

\subsection{Agent's act on behalf and in the name of the principal}

The will theory and the civil law legal system assert that there is no contract between the principal and the third party if there is no meeting of mind. ${ }^{48}$ In the common-law, on the other hand, the agent may bind the principal even if he acts in his name. ${ }^{49}$ Under Ethiopian law, the commercial agent should act "in the name and on behalf of the trader". ${ }^{50}$ By virtue of this phrase, it may be argued that undisclosed agency has no place in commercial agency law of Ethiopia. The Ethiopian Civil Code also provides that if the agent acts on his own behalf, he "shall personally enjoy the right or incur the liabilities deriving from the contract he makes with third parties, notwithstanding that such third parties know that he is an agent." ${ }^{, 51}$

\footnotetext{
${ }^{46}$ Wilhelmsson (2006), supra note 12, p. 143.

${ }^{47}$ Commercial Code of Ethiopia, 1960, Article 44.

${ }^{48}$ Rasmusen (2001) supra note 25, p 29 \& Aljasmi (2015), supra notes 9, p. 204

${ }^{49}$ Id., p 189.

${ }^{50}$ Commercial Code of Ethiopia, 1960, Article 44.

${ }^{51}$ Civil Code of Ethiopia 165/1960, Article 2197.
} 


\section{Mandatory Compensation upon Termination}

\subsection{Rationale of mandatory compensation and comparative approaches}

The main rationale behind classical commercial agency law was protecting the principal who trusted the agent. ${ }^{52}$ Accordingly, most agency rules focus on the obligation the agent has towards the principal. However, recent laws as stated earlier, incline towards the protection of the commercial agent, usually considered to be a weaker party. ${ }^{53}$

One of the schemes in this regard is mandatory compensation upon termination of a commercial agency, and this has evoked extensive academic discourse in commercial agency law. The primary rationale for mandatory compensation is the argument that the agent is the weaker party worth of protection, and commercial agency law should have protection of the weaker party as its primary object. ${ }^{54}$ As highlighted in the introduction, there are opponents of this view and they argue that the principal may shift the cost to the agent because the mandatory payment creates compliance cost. They also contend that the agent may not be the weaker party in some circumstances. ${ }^{55}$

There are three approaches in relation to mandatory payments upon termination of commercial agency agreements. These are the indemnity approach of the French model, the compensation approach of the German model and the British model which incorporates both the indemnity and the compensation models. The European Council Directive on the Coordination of the Laws of the Member States Relating to self-Employed Commercial Agents $653 / 1986$ oblige member states to adopt either the indemnity approach or the compensation approach. ${ }^{56}$

Under the French Commercial Code, upon the termination of the agency agreement, "commercial agents shall be entitled to an indemnity for the loss suffered". ${ }^{57}$ In the European Council Directive, the agent shall be entitled to an indemnity if "he has brought the principal new customers or has significantly increased the volume of business with existing customers and the principal continues to derive substantial benefits from the business with such customers" ${ }^{58}$ Indemnity is therefore due for the additional values the business of the principal has gained due to the efforts of the agent. In the British system,

\footnotetext{
${ }^{52}$ Wilhelmsson (2006), supra note12, p. 142.

${ }^{53}$ Study Group on a European Civil Code Principles \& Research Group on EC Private Law, (2009) supra note 37, p. 1.

${ }^{54}$ Wilhelmsson (2006), supra note 12, p 147.

${ }^{55}$ QI Zhou (2014), supra note 3, pp. 358-359.

${ }^{56}$ The European Council Directive 653/1986, Article 17.

${ }^{57}$ French Commercial Code, Article L 134-12.

${ }^{58}$ The European Council Directive 653/1986, Article 17.
} 
indemnity is payable if it is agreed upon between the agent and the principal in the agency agreement. ${ }^{59}$

The Compensation approach, on the other hand, takes into account the potential loss the agent faces due to the termination of the agency agreement. Under the British model, compensation shall be paid to the agent if the agency agreement did not contain indemnity clauses and the agency agreement is terminated in circumstances which:

... deprive the commercial agent of the commission which proper performance of the agency contract would have procured for him whilst providing his principal with substantial benefits linked to the activities of the commercial agent; or ... have not enabled the commercial agent to amortize the costs and expenses that he had incurred in the performance of the agency contract on the advice of his principal.

The first condition is linked with the commission -the commercial agent would have acquired had the agency agreement continued- and the benefit the principal gains due to the performance of the agent. The second circumstance does not consider the benefit the principal has acquired. It rather focuses on reimbursing the costs incurred by the agent in the interest of the business of the principal.

Generally, mandatory compensation/indemnity is meant to protect the agent. The principal may want to reach customers directly after effective market entry of his products due to the efforts of the agent and may terminate the agency agreement. The agent may also lose investments made in the interest of the activity he had been doing in relation with the work entrusted to him by the principal. The principal may also continue to benefit from the new customers brought by the efforts of the agent even after the termination of the agency. Therefore, the agent needs to be compensated.

\subsection{Ethiopian law on compensation upon termination of commercial agency}

The Commercial Code provides for compensation upon termination of commercial agency, and it states two cumulative conditions that are required for the payment of compensation, namely: undefined period of time as the duration of agency and absence of good cause. Article 53 reads:

Where the principal terminates without good cause an agency agreement entered into for an undefined period of time, the agent shall receive fair compensation which shall be fixed having regard in particular to the time for

\footnotetext{
${ }^{59}$ British Commercial Agents (Council Directive) Regulations 3053/1993, Article 17.
} 
which he acted on behalf of the principal and to the customers introduced or goodwill created or extended by him.

Since goodwill is an important component of any business, commercial agents usually have a certain contribution in the business of the principal. ${ }^{60}$ Therefore, "in paying compensation, the principal is buying the agent's patrimonial entitlement rather than redressing future losses". ${ }^{61}$ The other argument is that, as discussed above, the agent might have incurred cost in the interest of marketing the business.

Since compensation upon termination is for the goodwill the agent has created or the cost incurred by the agent in relation to the business of the principal, there is no justification for the omission of such compensation (from Article 53 of the Commercial Code) where agency relations for a definite period of time is terminated by the principal without good cause. The same reasons (i.e., undue advantage from goodwill created by an agent, and cost incurred by the latter) apply for agents whose agency is unduly terminated before the end of the definite period stated in the contract.

In many legal systems, compensation upon termination of the agency agreement is taken as a mandatory statutory provision that obliges the principal to pay irrespective of the causes of the termination. The principal is therefore, required to pay compensation upon termination of the agreement even if the agency is terminated legally. ${ }^{62}$ The EU directive, for example, states that indemnity/compensation shall be due even if the agency relation is terminated due to the death, illness, age and infirmity of the agent. ${ }^{63}$ But, the agent may not be entitled for compensation/indemnity if the agency agreement is terminated by the principal due to the fault of the agent -that can justify the termination of agency contract under the law- and if the agent willingly terminates the agency agreement without any fault from the principal. ${ }^{64}$

Under Ethiopian law, the agent is entitled to compensation if the principal, as stated above, terminates the agency agreement "without good cause". ${ }^{65}$ The phrase 'without good cause' should be interpreted with caution and the agent should, for example, be compensated if he has not committed fault that has caused the termination of agency. Unless indicative standards of 'good cause'

${ }^{60}$ AsmaVranaki (2008), 'Compensation for Commercial Agents', The Modern Law Review Vol. 71, No. 2 , pp. 271-279.

${ }^{61}$ Id., p. 503.

${ }^{62}$ Wilhelmsson (2006) supra note 12, p. 148.

${ }^{63}$ The European Council Directive 653/1986, Article 18 (a \& b).

${ }^{64}$ Id., Article 18 (b \& c).

${ }^{65}$ Ethiopian Commercial Code (1960), Article 53. 
are stated, its definition becomes susceptible to unpredictable and inconsistent judicial discretion.

It is, however, to be noted that the agent deserves compensation only if $\mathrm{s} / \mathrm{he}$ has enhanced the goodwill of the business and if the principal continues to drive benefits thereof. With regard to cost incurred by the agent who is not entitled to compensation (or indemnity) upon termination of agency, the agent may claim damages under the general law of obligations.

\subsection{Amount of compensation}

There are two approaches in determining the amount of compensation/indemnity to an agent upon the termination of commercial agency, i.e., the fixed amount approach and determination of the amount based on damage assessments. Many civil law countries like Germany and France have adopted the fixed amount approach. In Germany, for example, the amount of the indemnity is a one-year commission that is determined based on the average of five years commission. The amount of compensation in France is two times the annual average commission the agent used to get during the last three years. ${ }^{66}$ Dutch courts may grant up to a one year commission if they find the circumstances equitable. ${ }^{67}$ In UK, the compensation/indemnity due for the agent should be calculated taking into account the performance of the agent and the business status of the principal. $^{68}$

Article 53 of the Ethiopian Commercial Code, as stated above, provides that the calculation of the payment should be made taking into account "the time for which he acted on behalf of the principal and to the customers introduced or goodwill created or extended by him." Evaluation of goodwill needs clarity and there should be indicative elements, in addition to the general definition embodied in Article 130 of the Commercial Code.

An issue might also arise whether the principal or the new agent should ultimately bear the cost. There are arguments that the cost "should represent the cost of the succeeding agent for purchasing the agency (i.e the goodwill created by the leaving agent)." ${ }^{69}$ It seems appropriate that the principal should bear the cost, and there should be supplementary remedies against the succeeding agent.

${ }^{66}$ Commission of The European Communities (1996), 'Report on the application of article 17 of Council Directive on the Co-ordination of the laws of the Member States Relating to Self-Employed Commercial Agents (86/653/eec)', Brussels, pp. 2-5.

${ }^{67}$ Suzan Lap (2011), 'Commercial Agency Agreement under Dutch Law', in Cristelle Albaric \& Marianne Dicksted (eds. 2011), International Commercial Agency and Distribution Agreements: Case Law and Contract Clauses, pp. 773-8, Kluwer Law International, the Netherlands.

${ }^{68}$ Zhou,(2014), supra note 3, p. 359.

${ }^{69}$ Vranaki (2008) supra note 60, p. 274. 


\section{Conclusion}

The compensation/indemnity to be paid for a commercial agent upon the termination of agency is related with (i) the goodwill of the principal's business toward the creation of which the agent has contributed, (ii) the cost the agent has incurred in the interest of the business, and (iii) the loss of future commission he would have gained had the agency continued. The Ethiopian Commercial Code recognizes mandatory compensation if the principal terminates a commercial agency which is created for an indefinite period of time without 'good cause'. Thus, compensation for the termination of commercial agency - under in the Commercial Code- is a fault-based.

However, the theoretical justification of mandatory compensation discussed in this comment and the transformation of agency law from prime focus on principal protection to due attention to agent protection, warrant broader mandatory compensation upon termination of commercial agency. Distinction should not be made between definite or indefinite period of the agency contract, as long as the agency relation is not terminated due to the fault of the agent. The law should, however, take into account the benefits the principal continues to earn after the termination of the agency.

Therefore, the Ethiopian commercial agency law should recognize mandatory compensation for the commercial agent upon termination of the agency agreement if (i) the agency agreement is not terminated due to the fault of the agent, and (ii) if the principal continues to operate in the area and continues to derive benefits from the goodwill the agent has brought to the business. On the other hand, compensation should not be expected to be granted if the principal decides to stop working in the area or incurs loss or is declared bankrupt. With regard to the amount of compensation, lessons can be drawn from the good practices of other legal regimes toward fixed amount of compensation based on the duration of the agent's services, the level of consumer attraction, creation of goodwill and the continuity of the principal's benefits after the termination of the agency. 